\title{
The effect of admission to intensive care unit on outcomes and complication rates after head and neck reconstruction
}

F. Carta ${ }^{1}$, A. Figus ${ }^{2}$, N. Chuchueva ${ }^{1,3}$, D. Quartu ${ }^{1}$, G. B. Sambiagio ${ }^{4}$, R.F. Loche ${ }^{1}$, C. Gerosa ${ }^{5}$, R. Puxeddu ${ }^{1}$

${ }^{1}$ Unit of Otorhinolaryngology, Department of Surgery, University Hospital, University of Cagliari; Italy, 09124 Cagliari, Via Ospedale, 54; ${ }^{2}$ Unit of Plastic Surgery \& Microsurgery, Department of Surgery, University Hospital, University of Cagliari; Italy, 09124 Cagliari, Via Ospedale, 54;

${ }^{3}$ I.M. Sechenov First Moscow State Medical University, Ministry of Health of Russia; Russia 119991 Moscow, Bol'shaya Pitogovskaya St., 2, Build. 4;

${ }^{4}$ NHS Lanarkshire Glasgow; United Kingdom, Scotland, Glasgow;

${ }^{5}$ Unit of Pathology, Department of Surgery, University Hospital, University of Cagliari; Italy, 09124 Cagliari, Via Ospedale, 54

Contact: Roberto Puxeddu puxeddu@unica.it

The study objective is to evaluate the utilisation and effectiveness of intensive care unit (ICU) in the postoperative period as to its potential benefits to the head and neck reconstruction services.

Materials and methods. This is a retrospective study on 143 consecutive patients who underwent 144 major head and neck microvascular reconstructive procedures performed by a single surgeon, that focused on perioperative management and on the relation between admission to ICU and complications/outcomes.

Results. Thirty-four (23.6\%) patients were admitted to ICU during the early postoperative period. Admission to ICU was not associated with lower incidence of complications compared to direct admission to the Head and Neck ward: $29.4 \%$ vs $27.3 \%(p=0.807709)$.

Conclusion. Routinely early postoperative admission to ICU seems not to improve outcomes and/or reduce complications, and, as a consequence, ICU admission should be restricted to selected patients only.

Key words: head and neck cancer, microvascular free flap, elderly, intensive care unit

For citation: Carta F., Figus A., Chuchueva N. et al. The effect of admission to intensive care unit on outcomes and complication rates after head and neck reconstruction. Opukholi golovy $i$ shei = Head and Neck Tumors 2018;8(3):61-71.

DOI: $10.17650 / 2222-1468-2018-8-3-61-71$

\section{Влияние интенсивной терапии на исходы и частоту осложнений} после реконструктивных операций в области головы и шеи

\section{Ф. Карта ${ }^{1}$, А. Фигус ${ }^{2}$, Н. Чучуева ${ }^{1,3}$, Д. Кварту ${ }^{1}$, Дж. Б. Самбьяджко ${ }^{4}$ Р.Ф. Локе ${ }^{1}$, К. Джероза ${ }^{5}$, Р. Пукседу ${ }^{1}$}

${ }^{1}$ Блок оториноларингологии хирургического отделения клиники Университета Кальяри; Италия, 09124 Кальяри, виа Оспедале, 54; ${ }^{2}$ блок пластической хирургии и микрохирургии хирургического отделения Университета Кальяри; Италия, 09124 Кальяри, виа Оспедале, 54;

${ }^{3}$ ФАОУ ВО Первый Московский государственный медицинский университет им. И. М. Сеченова Минздрава России; Россия, 119991 Москва, ул. Большая Пироговская, 2, стр. 4;

${ }^{4}$ Национальная система здравоохранения Ланаркшир Глазго; Великобритания, Шотландия, Глазго;

${ }_{5}^{5}$ патологоанатомический блок хирургического отделения клиники Университета Кальяри; Италия, 09124 Кальяри, виа Оспедале, 54

Цель исследования - оценить значение интенсивной терапии (ИТ) в послеоперационном ведении пациентов после реконструктивных операций в области головы и шеи.

Материалы и методы. В данное ретроспективное исследование методом сплошной выборки были включены 143 пациента, у которых были выполнены 144 микрососудистые реконструктивные операции в области головы и шеи. Все операции были проведены одним хирургом.

Результаты. В отделение ИТ в раннем послеоперационном периоде были переведены 34 (23.6 \%) пациента. Перевод пациентов в отделение ИТ не был взаимосвязан с более низкой частотой развития осложнений по сравнению с переводом непосредственно в отделение хирургии головы и шеи: $27.3 \%$ vs $29.4 \%$ (

Заключение. Перевод в плановом порядке в отделение ИТ в раннем послеоперационном периоде не улучшает исходы и не уменьшает частоту осложнений, $и$, как следствие, перевод в отделение ИТ оправдан только в отдельных случаях.

Ключевые слова: злокачественные опухоли головы и шеи, микрососудистый свободный лоскут, пожилые пациенты, отделение интенсивной терапии 
Для цитирования: Карта Ф., Фигус А., Чучуева Н. и др. Влияние интенсивной терапии на исходы и частоту осложнений после реконструктивных операций в области головы и шеи. Опухоли головы и шеи 2018;8(3):61-71.

\section{Introduction}

Nowadays, microvascular free flap reconstruction is an essential step in the treatment of head and neck malignancies [1] because it offers the opportunity to perform an oncologic sound surgical resection associated with the immediate repair of complex 3-dimensional structures, improving patients' quality of life and survival [2]. Although patients may suffer from general surgical complications such as bleeding and/or infection, free flap failure, due to irreversible arterial or venous thrombosis, is one of the most important complications to be avoided. Close monitoring has been demonstrated successful in reducing these complications but, whether Intensive Care Unit (ICU) must be considered as an integral part of the postoperative management of the patients undergoing head and neck free flap reconstruction or not, it is still unclear [3]. The present study analysed the selection criteria and the outcomes of all consecutive patients undergoing ablative surgery followed by microvascular reconstruction for head and neck malignancies in our centre. Complications, failures and impact of the admission to ICU in the early postoperative management were investigated. Moreover, differences between elderly $v s$ young patients and presence of comorbidities were assessed to identify potential contributing factors.

The aim of the study was to evaluate the utilisation and effectiveness of ICU in the postoperative period as to its potential benefits to the head and neck reconstruction services.

\section{Materials and methods}

From November 2011 till January 2017, a retrospective review was carried on a consecutive series of 143 patients who underwent 144 reconstructive microsurgical procedures performed by the same ENT head and neck surgeon (RP) in the Department of Otorhinolaryngology of a tertiary oncological Centre (Ethic Committee approval number NP/2018/895).

Patients were considered for free flap reconstruction during the primary treatment for head and neck malignancies at early and advanced stages, or after recurrent disease or inadequate reconstructions performed in other Centres. Previous chemotherapy and/or radiotherapy were not exclusion criteria alone, but were correlated with age and comorbidities, according to the Age Adjusted Charlson Comorbidity Index (AACCI) [4]. Fragile elderly patients with AACCI $>5$, were generally submitted to simpler reconstructive procedures with pedicled flaps.

Preoperative histologic diagnosis was obtained in all patients with head and neck lesions. All patients were restaged according to the $8^{\text {th }}$ edition of the Union for International Cancer Control - American Joint Committee on Cancer TNM staging system [5].
Patients with head and neck malignancy underwent wide radical excision of the primary tumour with ipsilateral or bilateral neck dissection (according to the site of the tumour and the risk for nodal involvement) followed by free flap reconstruction. All patients received a single bolus of heparin sodium (1500 IU) at least $5 \mathrm{~min}$ before the transfer of the flap. Anastomosis was performed under microscope (ZEISS S7, focal length $250 \mathrm{~mm}$ ); synthetic non-absorbable $8 / 0$ or $9 / 0$ nylon suture were used. Arterial anastomosis was performed with synthetic non-absorbable $8 / 0$ or $9 / 0$ nylon suture. Venous anastomosis was performed with the coupler device (Microvascular Anastomotic Coupling System, Synovis Life Technologies). Defects in the head and neck region were classified into 6 anatomical reconstructive regions: pharyngo-laryngeal, oropharyngeal, oral, mandibular, midfacial, and cutaneous. Mucosal defects included tongue, floor of mouth, oropharynx, hypopharynx, and cervical oesophagus. Oncological surgical defects of the oral cavity, base of the tongue and pharynx affecting swallowing and speech were restored with the use of thin and pliable flap. The radial forearm free flap was the first choice for intra-oral reconstruction. Sub-total or total glossectomy was reconstructed with composite rectus abdominis myocutaneous free flap, while segmental and subtotal mandibulectomies required a composite bony free flap as iliac crest or fibula flaps.

Postoperative treatment consisted of antibiotic therapy (ceftriaxone $2 \mathrm{~g}$ per day and metronidazole $500 \mathrm{mg} 3$ times a day for 7-10 days), low molecular weight heparin (enoxaparin sodium) in a prophylactic dosage (range of 3000-8000 IU per day) and anti-embolism stocking. Feeding tube was inserted in all patients treated for upper aero digestive tract malignancy. Temporary tracheostomy was performed to avoid postoperative respiratory distress, but its need was discussed in selected cases with facial skin reconstruction and limited neck dissection (it was avoided in 2 cases). Intraoperative and postoperative fluid balance was routinely evaluated with the goal to maintain intravascular fluid volume for optimal tissue blood flow and oxygenation.

During the first 31 procedures, patients older than 65 years or with chronic impairment of 1 or more organ systems were routinely admitted to the ICU for haemodynamic and airway monitoring. During the last 113 procedures patients were monitored in an equipped room in the ward, whilst the indication for recovery in ICU were the need of advanced respiratory support, sustenance of 2 or more organ systems, patients with chronic impairment of 1 or more organ systems sufficient to restrict daily activities, patients with acute reversible failure of 1 system, or when an extensive haemodynamic imbalance developed during surgery (see fig.). 
- Need of advanced respiratory support / sustenance of 2 or more organ systems / Необходимость в поддержании дыхания или функиионирования 2 и более систем органов

- Patients with severe chronic impairment of 1 or more organ systems / Пачиенты с тяжелыми хроническими заболеваниями 1 или более систем органов

- Patients with acute reversible failure of 1 system / Пациенты с острым обратимым нарушением функционирования 1 системы органов

- Perioperative: / Периоперационные:

- haemodynamic imbalance / нарушения гемодинамики

- renal/kidney imbalance / нарушение работы почек

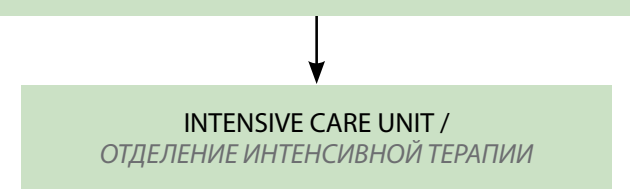

- No need of advanced respiratory support / sustenance of more than 1 organ systems / Oтсутствие необходимости в поддержании дыхания или функционирования >1 системы органов

- Patients without severe chronic impairment of organ systems / Пациенты без тяжелых хронических заболеваний органов и систем

- No recent acute failure of organ systems / Omcymcmвue серьезных нарушений в работе органов и систем в недавнее время

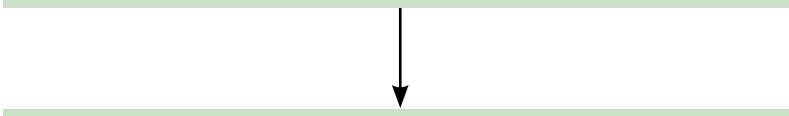

- Room in the ward equipped with $\mathrm{O}_{2}$ monitoring system / Палата в отделении оборудована системой мониторинга насыщения крови кислородом

- Dedicated nurse/specialist registrar for 48 hours / Специально выделенные медсестра или специалист, наблюдающие за пачиентом в течение 484

Algorithm for postoperative intensive care unit admission

Алгоритм послеоперационной госпитализации в отделение интенсивной терапии

A trainee ENT specialist registrar and/or a head and neck experienced nurse, monitored the flap every hour during the first 2 days, and every 2 to 4 hours up to 5 postoperative days as from internal protocol. In case of doubtful flap survival, the surgeon was promptly called to evaluate the situation as to go back to theatre for exploration and flap salvage.

Outcome parameters included length of hospital stay and complications. According to E. M. Genden et al. [6] and the Clavien-Dindo system [7], complications were divided into surgical donor-site and flap complications (requiring surgical re-exploration) or non-surgical donor-site and flap complications managed with medical therapy. According to E.O. Dimovska et al., complications were also divided in early and late complications, when observed within and after the first 30 postoperative days respectively [8]. Donor-site complications include seroma, haematoma, infection, dehiscence, venous congestion and skin loss. Flap complications include partial or total flap failure, cervical hematoma, surgical site infection, wound dehiscence, fistula. Postoperative arrhythmia, myocardial infarction, pulmonary oedema, postoperative hypertension, deep vein thrombosis, pulmonary embolism, acute renal failure, respiratory failure, pneumonia and sepsis are classified as systemic complications.

Adjuvant therapy was planned for advanced $\mathrm{T}$ stage (pT3 or pT4), multiple positive nodes, and/or per neural/lymphatic/vascular invasion [9].

All patients were addressed for regular follow-up according to the American Head and Neck Society guidelines [10] (mean time of 3.4 years, median time of 1.8 years, range of 6 months -7 years). A disease-free state was defined as the absence of cancer demonstrated by head and neck surgeon and imaging, and (if necessary) pathological examination following biopsy, while the definition of disease state was referred to the presence of a local, regional or lo$\mathrm{co} /$ regional relapse and/or distant metastases.

Comorbidities were categorized retrospectively using the AACCI [4]. In the present study one of the goals was to compare complications and outcomes between elderly ( $\geq 65$ years) vs young ( $<65$ years) patients, between patients with AACCI $\leq 5 v s$ patients with AACCI $>5$, and between patients admitted in ICU during the early postoperative period $v s$ patients treated only in the ward after surgery.

Recurrence time was assessed from the date of surgery to the date of the first recurrence. Five-year overall survival (OS), disease specific survival (DSS) and relapse-free survival (RFS) were calculated using the Kaplan-Meier method. Survival rates and univariate analysis were calculated using GraphPad Prism software (GraphPad, San Diego, CA, USA). Chi-squared analysis with Fischer's exact test was performed to determine the influence of age on complication rate, morbidity and functional outcome. Statistical significance was defined as $p<0.05$.

\section{Results}

Overall, 143 consecutive patients underwent 144 microsurgical reconstructions after ablative surgery for head and neck cancers. Age distribution, types of cancer, site of reconstruction and the types of free flap are shown in table 1.

Seven patients were previously submitted to neoadjuvant chemotherapy; 7 patients were treated after failure of chemoradiotherapy, and 10 procedures were performed in patients with recurrent cancer surgically treated elsewhere (in 5 cases previous surgical treatments had been associated with radiotherapy). One hundred forty-two patients underwent 143 single-stage microsurgical reconstructions 
Table 1. Patients' age distribution

Таблица 1. Распределение пациентов по возрасту

\begin{tabular}{|c|c|}
\hline $\begin{array}{l}\text { Parameter } \\
\text { Показагель }\end{array}$ & $\begin{array}{l}\text { Value } \\
\text { Значение }\end{array}$ \\
\hline \multicolumn{2}{|l|}{ All patients, $\boldsymbol{n}=\mathbf{1 4 4}$} \\
\hline $\begin{array}{l}\text { Mean age, years } \\
\text { Средний возраст, лет }\end{array}$ & 58.3 \\
\hline $\begin{array}{l}\text { Age range, years } \\
\text { Диапазон возраста, лет }\end{array}$ & $25-82$ \\
\hline $\begin{array}{l}\text { Younger }(<65 \text { years), abs }(\%) \\
\text { Пациенты среднего возраста }(<65 \text { лет), абс. (\%) }\end{array}$ & $111(77.1)$ \\
\hline $\begin{array}{l}\text { Young old (65-74 years), abs. (\%) } \\
\text { Пациенты пожилого возраста (65-74 года), абс. (\%) }\end{array}$ & $21(14.6)$ \\
\hline $\begin{array}{l}\text { Older and oldest old ( } \geq 75 \text { years), abs. }(\%) \\
\text { Пациенты старческого возраста }(\geq 75 \text { лет), абс. (\%) }\end{array}$ & $12(8.3)$ \\
\hline \multicolumn{2}{|l|}{ Male, $n=116(80.6 \%)$} \\
\hline $\begin{array}{l}\text { Mean age, years } \\
\text { Средний возраст, лет }\end{array}$ & 57.9 \\
\hline $\begin{array}{l}\text { Age range, years } \\
\text { Диапазон возраста, лет }\end{array}$ & $25-82$ \\
\hline \multicolumn{2}{|l|}{ Female, $n=28(\mathbf{1 9 . 4 \% )}$} \\
\hline $\begin{array}{l}\text { Mean age, years } \\
\text { Средний возраст, лет }\end{array}$ & 60.0 \\
\hline $\begin{array}{l}\text { Age range, years } \\
\text { Диапазон возраста, лет }\end{array}$ & $34-83$ \\
\hline
\end{tabular}

following resection of head and neck malignancies, and 1 patient underwent microsurgical reconstruction after previous failed pedicled flap reconstruction performed in different institution. Stage of patients with squamous cell carcinoma $(n=135)$ and all the microvascular free flap procedures reported in the present series are detailed in tables $1-4$.

Harvesting of the forearm flap was performed with the use of an arm tourniquet and it included always both the cutaneous venous system (cephalic vein) and the radial deep venous system (comitantes veins).

The facial artery was chosen in $65.3 \%$ as recipient artery $(n=94)$, followed by the superior thyroid artery in $26.4 \%(n=38)$, lingual artery in $7.6 \%(n=11)$ and the external carotid in $0.7 \%(n=1)$.

Venous drainage was obtained with a single anastomosis in $110(76.4 \%)$ cases. In the majority of the cases the recipient vein was one of the branches of the thyro-lingualfacial trunk (134 procedures, 168 microanastomosis), but in 9 cases an end-to-side anastomosis to the internal jugular vein was performed, and in 1 case, the external jugular vein was used as recipient vein. In 1 case the limited pedicle's
Table 2. Patients' distribution according to site of reconstructions and histology, $n=144$

Таблища 2. Распределение пациентов по области реконструктивного вмешательства и гистологическому типу опухоли, $n=144$

\begin{tabular}{|c|c|c|}
\hline $\begin{array}{l}\text { Parameter } \\
\text { Показательь }\end{array}$ & $\begin{array}{c}\text { Number } \\
\text { of procedures, abs. } \\
\text { Количество } \\
\text { процедур, абс. }\end{array}$ & $\begin{array}{c}\text { Frequency, \% } \\
\text { Чacrora, } \%\end{array}$ \\
\hline \multicolumn{3}{|c|}{ Microvascular procedures } \\
\hline $\begin{array}{l}\text { Oral cavity } \\
\text { Ротовая полость }\end{array}$ & 111 & 77.1 \\
\hline $\begin{array}{l}\text { Oral cavity extended } \\
\text { to the maxilla } \\
\text { Ротовая полость } \\
\text { с вовлечением верхней } \\
\text { челюсти }\end{array}$ & 2 & 1.4 \\
\hline $\begin{array}{l}\text { Oropharynx } \\
\text { Ротоглотка }\end{array}$ & 14 & 9.7 \\
\hline $\begin{array}{l}\text { Pharynx and larynx } \\
\text { Глотка и гортань }\end{array}$ & 7 & 4.9 \\
\hline $\begin{array}{l}\text { Face } \\
\text { Лицо }\end{array}$ & 10 & 6.9 \\
\hline
\end{tabular}

\begin{tabular}{|c|c|c|}
\hline \multicolumn{3}{|c|}{ Histology } \\
\hline $\begin{array}{l}\text { Squamous cell } \\
\text { carcinoma } \\
\text { Плоскоклеточная } \\
\text { карцинома }\end{array}$ & 135 & 93.7 \\
\hline $\begin{array}{l}\text { Adenocarcinoma } \\
\text { Аденокарцинома }\end{array}$ & 3 & 2.1 \\
\hline $\begin{array}{l}\text { Synovial sarcoma } \\
\text { Синовиальная саркома }\end{array}$ & 1 & 0.7 \\
\hline $\begin{array}{l}\text { Mucoepidermoid } \\
\text { carcinoma } \\
\text { Мукоэпидермоидная } \\
\text { карцинома }\end{array}$ & 2 & 1.4 \\
\hline $\begin{array}{l}\text { Lymphoepithelial } \\
\text { carcinoma } \\
\text { Лимфоэпителиальная } \\
\text { карцинома }\end{array}$ & 1 & 0.7 \\
\hline $\begin{array}{l}\text { Sclerodermiform basal } \\
\text { cell carcinoma } \\
\text { Склеродермальная } \\
\text { базальноклеточная } \\
\text { карцинома }\end{array}$ & 1 & 0.7 \\
\hline $\begin{array}{l}\text { Previous failed } \\
\text { reconstructions } \\
\text { performed elsewhere } \\
\text { Неудачные реконструк- } \\
\text { тивные операции } \\
\text { в прошлом, выполнен- } \\
\text { ные в других местах }\end{array}$ & 1 & 0.7 \\
\hline
\end{tabular}


length (rectus abdominis free flap) required the interposition of a vein graft. The anastomosis of the vein was always performed with the coupler device. Seven patients received a permanent tracheostomy (total laryngectomy) and a temporary tracheostomy was performed in 135 , while 2 patients with limited neck dissection and reconstruction only of the facial skin in the parotid region did not need a tracheostomy.

Mean length of hospital stay was 23.8 days (range of 7-75 days); mean time for removal of the temporary tracheostomy was 9.9 days (range of 4-31 days); mean feeding tube permanence, when indicated $(n=126)$, was 22 days (range of $12-65$ days).

Thirty-four (23.6\%) patients were admitted to ICU during the early postoperative period: 21 patients during the first $31(67.7 \%)$ procedures and 13 patients during the last $113(11.5 \%)$ procedures.

Thirty-nine patients experienced $40(27.8 \%)$ complications after the surgical procedure, requiring 35 early $(n=29)$ or delayed $(n=6)$ surgical revisions (table 5). Bleeding occurred after $16(11.1 \%)$ procedures. Particularly, 12 patients were taken back to theatre for evacuation of haematoma in the neck ( 4 of these patients needed revision of the venous anastomosis) and 4 patients underwent surgery for haematoma in the donor site region. Venous congestion of the flap was observed in $9(6.2 \%)$ cases: in 1 case it recovered within 12 hours after therapy with steroids, in 5 cases it was successfully managed with a revision of the venous anastomosis (range of revision of 2 hours -2 days), and in 3 cases it was associated with flap failure (1 radial forearm flap, 1 iliac crest flap and 1 jejunum flap) and required a salvage

Table 3. Patients' distribution according to stages of head and neck squamous cell carcinomas (by $8^{\text {th }}$ edition of the American Joint Committee on Cancer TNM staging system, $n=135$ )

Таблища 3. Распределение пациентов по стадиям плоскоклеточных кариином головы и шеи (по 8-му изданию классификации TNM Американского объединенного комитета по изучению рака, $n=135$ )

\begin{tabular}{|c|c|c|c|c|c|}
\hline $\begin{array}{l}\text { Origin } \\
\text { Пронсхождение }\end{array}$ & $\begin{array}{l}\text { All } \\
\text { Bee }\end{array}$ & Stage I & $\begin{array}{l}\text { Stage II } \\
\text { II стадия }\end{array}$ & $\begin{array}{l}\text { Stage III } \\
\text { III стадия }\end{array}$ & $\begin{array}{l}\text { Stage IV } \\
\text { IV стадия }\end{array}$ \\
\hline $\begin{array}{l}\text { Oral cavity } \\
\text { Ротовая полость }\end{array}$ & $111^{*}$ & 8 & $29^{*}$ & 26 & 48 \\
\hline $\begin{array}{l}\text { Oropharynx } \\
\text { Ротоглотка }\end{array}$ & 11 & - & 4 & 4 & 3 \\
\hline $\begin{array}{l}\text { Pharynx and } \\
\text { larynx } \\
\text { Глотка и гортань }\end{array}$ & 6 & - & - & 1 & 5 \\
\hline $\begin{array}{l}\text { Face } \\
\text { Лицо }\end{array}$ & 7 & - & 1 & 2 & 4 \\
\hline \multicolumn{6}{|c|}{$\begin{array}{l}\text { *One patient experienced } 2 \text { different microvascular procedures } \\
\text { for } 2 \text { distinct metachronous squamous cell carcinomas of the oral } \\
\text { cavity of stage II in both cases. } \\
\text { *У } 1 \text { пациента были выполнены } 2 \text { разные микрососудистые } \\
\text { процедуры по поводу } 2 \text { различных метахронных плоскоклеточных } \\
\text { кариином полости рта II стадии. }\end{array}$} \\
\hline
\end{tabular}

reconstruction with pectoralis major pedicled flap (range of revision of 4-31 days). Two patients suffered loss of the skin paddle of iliac crest free flap. This last complication was observed after 10 and 15 days after surgery and was positively managed by a rotated bilateral Esser's skin flap. Three patients suffered for non-surgical complications: 2 cases of deep vein thrombosis and in 1 case of pulmonary embolism in a ClavienDindo grade IV patient, who needed admission to ICU.

Seven $(22.5 \%)$ early surgical complications occurred during the first 31 procedures, while 22 occurred during the last $113(19.5 \%)$ procedures $(p=0.701954)$. Nine early surgical complications ( $26.5 \%$ of the procedures) were observed during the recovery in the ICU, and $20(18.2 \%$ of the procedures) during the recovery in the ward $(p=0.292196)$. No significant difference in the overall incidence of postoperative complications was observed between patients admitted to ICU vs patients admitted to the ward $(p=0.807709)$. Patients admitted to ICU in the immediate postoperative period had a longer median length of hospital stay (27 days vs 21 days in the non-ICU group of patients; $p=0.3$ ). Postoperative complications were observed in $36.4 \%$ of the elderly patients and in $25.2 \%$ of the young patients $(p=0.171817)$. The most fragile patients (AACCI $>5$ ) experienced higher rate of postoperative complications: $44.4 \%$ of the cases, while only $23.9 \%$ of the patients with AACCI $\leq 5$ presented post-operative complications $(p=0.03195)$. Young fragile patients showed a moderately higher risk to experience postoperative complications, compared to the other groups of patients $(p=0.022812)$. We did not find any statistical correlation between age and/or comorbidities and total/ partial flap failures $(p=0.55)$ (table 6).

Fifty-seven $(39.6 \%)$ patients underwent adjuvant radiotherapy. During the follow-up, head and neck cancer recurred in $23(16 \%)$ patients; $6(4.2 \%)$ patients experienced a second head and neck malignancy, and 10 (6.9\%) patients developed pulmonary or cerebral metastasis. Fiveyear DSS, OS and RFS are shown in table 7.

\section{Discussion}

Vascularized tissue transferred from a distant donor site to a recipient site to reconstruct complex head and neck defects protects vascular structures and improve wound closure and long-term aesthetic and functional restoration. In our series the microvascular radial forearm, iliac crest and the rectus abdominis free flaps were the most frequently used for the purpose.

The radial forearm free flap offers a good versatility and reliability including the presence of additional drainage pathway with the cephalic vein. There is still a debate as to which venous system (cephalic or comitantes veins) should be anastomosed, but we found the anastomosis of the cephalic vein only was reliable in $71.6 \%$ of the cases $(n=78)$. This finding confirms the recent experience of S. Razzano et al. [11]. Adequate venous out-flow must be assured to guarantee the survival of free flaps. In literature a dual venous anastomosis has been related with lower failure rate 
Table 4. Microvascular free flap procedures of our series

Таблица 4. Микроваскулярная реконструкция с использованием свободных лоскутов

\begin{tabular}{|c|c|c|c|c|c|c|c|}
\hline \multirow{3}{*}{$\begin{array}{c}\text { Free flap } \\
\text { Свободный лоскуг }\end{array}$} & \multicolumn{7}{|c|}{$\begin{array}{l}\text { Number of procedures } \\
\text { Количество процедур }\end{array}$} \\
\hline & \multirow{2}{*}{$\begin{array}{l}\text { All, abs. } \\
\text { (\%) } \\
\text { Bce, }\end{array}$} & \multicolumn{6}{|c|}{ in depending on the surgical procedure area } \\
\hline & & Oral cavity & $\begin{array}{c}\text { Oral cavity with } \\
\text { maxillectomy }\end{array}$ & $\begin{array}{l}\text { Oral cavity with } \\
\text { mandibulectomy }\end{array}$ & Oropharynx & $\begin{array}{c}\text { Pharynx } \\
\text { and larynx }\end{array}$ & Face \\
\hline $\begin{array}{l}\text { Forearm } \\
\text { Предплечье }\end{array}$ & $109(75.7)$ & 82 & 1 & - & 14 & 5 & 7 \\
\hline $\begin{array}{l}\text { Rectus abdominis } \\
\text { Прямая мышца живота }\end{array}$ & $11(7.6)$ & 6 & 1 & - & - & 1 & 3 \\
\hline $\begin{array}{l}\text { Fibula } \\
\text { Малоберцовая кость }\end{array}$ & $2(1.4)$ & - & - & 2 & - & - & - \\
\hline $\begin{array}{l}\text { Iliac crest } \\
\text { Подвздошный гребень }\end{array}$ & $21(14.6)$ & - & - & 21 & - & - & - \\
\hline $\begin{array}{l}\text { Jejunum } \\
\text { Тощая кишка }\end{array}$ & $1(0.7)$ & - & - & - & - & 1 & - \\
\hline $\begin{array}{l}\text { Total } \\
\text { Bcero }\end{array}$ & $144(100)$ & 88 & 2 & 23 & 14 & 7 & 10 \\
\hline
\end{tabular}

Table 5. Frequency of complications in depending on flap type

Таблища 5. Частота осложнений в зависимости от вида лоскута

\begin{tabular}{|c|c|c|c|c|c|c|}
\hline $\begin{array}{l}\text { Complications } \\
\text { Осложнения }\end{array}$ & $\begin{array}{l}\text { Jejunum } \\
\text { Топая } \\
\text { киाшка }\end{array}$ & $\begin{array}{l}\text { Forearm } \\
\text { Предшечье }\end{array}$ & $\begin{array}{l}\text { Iliac crest } \\
\text { ПодвздонНьй } \\
\text { гребеньь }\end{array}$ & $\begin{array}{l}\text { Rectus abdominalis } \\
\text { Прямая мышाща } \\
\text { жиявота }\end{array}$ & $\begin{array}{l}\text { Fibula } \\
\text { Maлоберновая } \\
\text { кость }\end{array}$ & $\begin{array}{c}\text { All, abs. (\%) } \\
\text { Bсег, aбc. } \\
(\%)\end{array}$ \\
\hline $\begin{array}{l}\text { Flap failure } \\
\text { Полный некроз лоскута }\end{array}$ & 1 & 1 & 1 & - & - & $3(2.1)$ \\
\hline $\begin{array}{l}\text { Near flap failure } \\
\text { Частичный некроз лоскута }\end{array}$ & - & 6 & - & - & - & $6(4.1)$ \\
\hline $\begin{array}{l}\text { Cervical bleeding without flap } \\
\text { sufferance } \\
\text { Шейное кровотечение без } \\
\text { отторжения лоскута }\end{array}$ & - & 8 & - & - & - & $8(5.5)$ \\
\hline $\begin{array}{l}\text { Head and neck suture dehiscence } \\
\text { Расхождение швов в области } \\
\text { головы и шеи }\end{array}$ & - & 1 & 1 & 2 & 1 & $5(3.5)$ \\
\hline $\begin{array}{l}\text { Delayed revision of the flap } \\
\text { Поздняя ревизия лоскута }\end{array}$ & - & 1 & 3 & 1 & - & $5(3.5)$ \\
\hline $\begin{array}{l}\text { Foreign body } \\
\text { Инородное тело }\end{array}$ & - & - & - & 1 & - & $1(0.7)$ \\
\hline $\begin{array}{l}\text { Donor site hematoma } \\
\text { Гематома донорского участка }\end{array}$ & - & 3 & 1 & - & - & $4(2.8)$ \\
\hline $\begin{array}{l}\text { Donor site suture dehiscence } \\
\text { Расхождение швов в области } \\
\text { донорского участка }\end{array}$ & - & 2 & 1 & - & - & $3(2.1)$ \\
\hline $\begin{array}{l}\text { Salivary fistula/abscess } \\
\text { Свищ/абсцесс слюнной железы }\end{array}$ & - & 1 & 1 & - & - & $2(1.4)$ \\
\hline $\begin{array}{l}\text { Deep vein thrombosis } \\
\text { Тромбоз глубоких вен }\end{array}$ & - & 2 & - & - & - & $2(1.4)$ \\
\hline $\begin{array}{l}\text { Pulmonary embolism } \\
\text { Легочная эмболия }\end{array}$ & - & 1 & - & - & - & $1(0.7)$ \\
\hline $\begin{array}{l}\text { Total } \\
\text { Bcezo }\end{array}$ & 1 & 26 & 8 & 4 & 1 & $40(27.8)$ \\
\hline
\end{tabular}


Table 6. Distribution of the complications in the different groups of patients, abs. (\%)

Таблица 6. Распределение пациентов в зависимости от частоты осложнений в разных группах, абс. (\%)

\begin{tabular}{|c|c|c|c|c|c|c|c|c|}
\hline $\begin{array}{l}\text { Group of patients } \\
\text { Групта паштенов }\end{array}$ & $\begin{array}{c}\begin{array}{c}\text { Number } \\
\text { of proce- } \\
\text { dures }\end{array} \\
\text { Количество } \\
\text { процедур }\end{array}$ & $\begin{array}{l}\text { Flap } \\
\text { failure } \\
\text { Полньй } \\
\text { некро3 } \\
\text { лоскуга }\end{array}$ & $\begin{array}{c}\text { Near } \\
\text { flap } \\
\text { failure } \\
\text { Часпич- } \\
\text { Ньй } \\
\text { некроз } \\
\text { лоскуга }\end{array}$ & $\begin{array}{l}\text { Other head and } \\
\text { neck compli- } \\
\text { cations } \\
\text { Друпие } \\
\text { осложнения } \\
\text { в области } \\
\text { головы и шеи }\end{array}$ & $\begin{array}{c}\text { Donor-site } \\
\text { complications } \\
\text { Осложнения } \\
\text { на донореком } \\
\text { участке }\end{array}$ & $\begin{array}{c}\text { Non-surgical } \\
\text { complications } \\
\text { Hexируртиче- } \\
\text { ские осложне- } \\
\text { ния }\end{array}$ & $\begin{array}{c}\text { All } \\
\text { Bcero }\end{array}$ & $p$ \\
\hline $\begin{array}{l}\text { AACCI } \leq 5 \text { elderly } \\
\text { patients } \\
\text { Пожилые пациенты } \\
\text { с АACCI } \leq 5\end{array}$ & 23 & $1(4.4)$ & - & $5(21.7)$ & $1(4.4)$ & $2(8.7)$ & $9(39.1)$ & \multirow{4}{*}{$\begin{array}{c}\text { Elderly } \\
\text { vs young patients } \\
\text { Между пожилыми } \\
\text { пациентами и более } \\
\text { молодыми } \\
0.171817\end{array}$} \\
\hline $\begin{array}{l}\text { AACCI }>5 \text { elderly } \\
\text { patients } \\
\text { Пожилые пациенты } \\
\text { с АACCI }>5\end{array}$ & 10 & - & - & $1(10.0)$ & $1(10.0)$ & $1(10.0)$ & $3(30.0)$ & \\
\hline $\begin{array}{l}\text { AАCCI } \leq 5 \text { young } \\
\text { patients } \\
\text { Более молодые } \\
\text { пациенты с AACCI } \leq 5\end{array}$ & 94 & $2(2.1)$ & $4(4.2)$ & $8(8.5)$ & $3(3.2)$ & $2(2.1)$ & $19(20.2)$ & \\
\hline $\begin{array}{l}\text { AACCI }>5 \text { young } \\
\text { patients } \\
\text { Более молодые } \\
\text { пациенты с АACCI }>5\end{array}$ & 17 & - & $2(11.8)$ & $4(23.5)$ & $3(17.6)$ & - & $9(52.9)$ & \\
\hline $\begin{array}{l}\text { Patients admitted } \\
\text { in intensive care unit } \\
\text { Пациенты, поступив- } \\
\text { шие в отделение } \\
\text { интенсивной терапии }\end{array}$ & 34 & $2(5.9)$ & $1(2.9)$ & $6(17.6)$ & $1(2.9)$ & - & $10(29.4)$ & \multirow{2}{*}{$\begin{array}{c}\text { Intensive care unit } v s \\
\text { no intensive care unit } \\
\text { Между пациентами, } \\
\text { помещенными } \\
\text { в отделение интенсив- } \\
\text { ной терапии и поме- } \\
\text { щенными в обычную } \\
\text { палату } \\
0.807709\end{array}$} \\
\hline $\begin{array}{l}\text { Patients admitted } \\
\text { in the ward } \\
\text { Пациенты, помещен- } \\
\text { ные в обычную палату }\end{array}$ & 110 & $1(0.9)$ & $5(4.5)$ & $12(10.9)$ & $7(6.4)$ & $5(4.5)$ & $30(27.3)$ & \\
\hline $\begin{array}{l}\text { Total (\% over all series) } \\
\text { Всего (\% от всех } \\
\text { пациентов) }\end{array}$ & 144 & $3(2.1)$ & $6(4.2)$ & $18(12.5)$ & $8(5.5)$ & $5(3.5)$ & $40(27.8)$ & - \\
\hline
\end{tabular}

Note. AACCI - Age Adjusted Charlson Comorbidity Index.

Примечание. ААССI - индекс коморбидности Чарлсона с поправкой на возраст.

(in the $1.51 \%$ vs $5.03 \%$ after single anastomosis), lower venous thrombosis rate $(2.74 \%$ vs $4.54 \%)$, and lower revision rate $(11.87 \%$ vs $6.04 \%)$ [12]. In our series $75.7 \%$ patients $(n=109)$ received a single venous anastomosis. In the present series, the number of the anastomosis did not influence the outcomes. Although flap failures $(n=3)$ were observed in patients with a single venous anastomosis, these occurred during the early period of our experience, and statistical analysis did not show any significant difference $(p=0.447)$. After an adequate intraoperative evaluation of the venous out-flow of the flap, a single anastomosis was generally preferred to minimize operative time, simplify pedicle geometry, avoid the use of vein grafts, preserve potential recipient veins for future free flaps, make surgery technically simpler by using a single proximal large confluent vein rather than two distal smaller venae comitantes minimizing the risk for low blood velocity. According to literature, the recipient veins were generally identified among the internal jugular vein system [13]. Venous anastomosis is one of the most challenging technical aspects of microsurgery, but it can be improved by the use of an anastomotic coupler device. It is quicker and more reliable in maintaining the anastomotic site patent and it could be used also as end-to-side technique on the internal jugular vein ( 2 cases in our series). We routinely used silastic Penrose drainage tubes to avoid active aspiration and limit any pressure on the microvascular pedicle. The radial forearm free flap was used in $75.7 \%$ of our microvascular procedures with a success rate of $99 \%$. Nevertheless, little bone reconstruction could be performed harvesting part of the radial bone with the flap ( 1 case in our series). Closure of the donor defect of the radial forearm flap required always a skin graft 
Table 7. Five-year disease specific survival, overall survival and relapse-free survival rates of patients with squamous cell carcinoma, $n=135$

Таблица 7. Пятилетняя онкоспецифическая, общая и безрецидивная выживаемость пациентов с плоскоклеточным раком, $n=135$

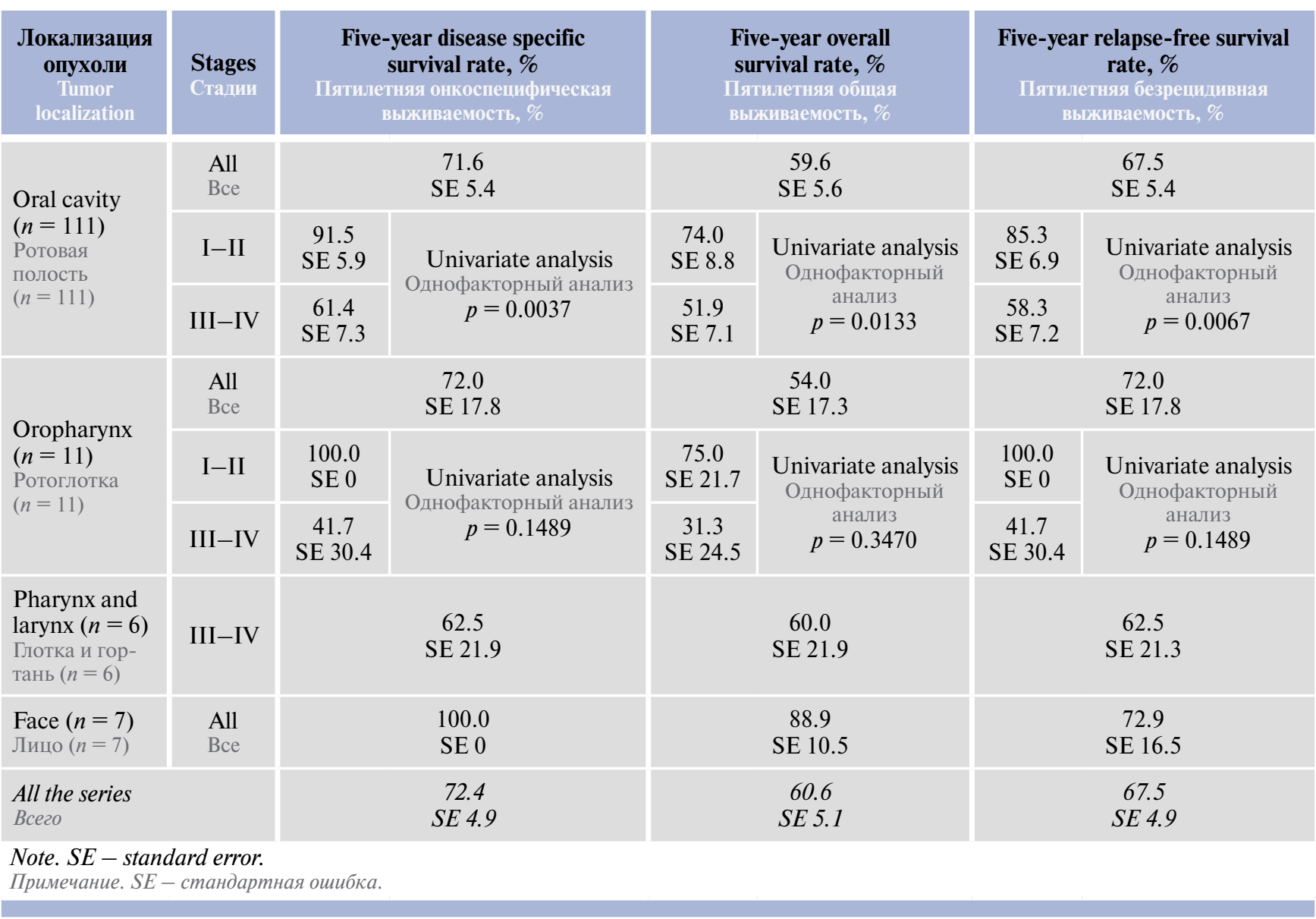

although we are aware of possibility of forearm advancement-rotation flaps [14]. Two patients required a revision of the donor site defect with a further skin graft.

Microsurgical vascularised osteo-myocutaneous free flaps are very useful for reconstruction of complex defects following maxillectomy and mandibulectomy [15, 16]. Both iliac crest and fibula free flaps can be considered the best option for mandibular reconstruction $[15,16]$. We preferred the use of the vascularized iliac crest flap. There are no significant differences in terms of morbidity of the donor site between iliac crest and fibula free flaps patients [17]. All patients of the present series experienced pain at the donor site, which lasted for a mean time of 1.7 months; nevertheless, a follow-up of more than 6 months showed no residual donor site morbidities. Necrosis of the cutaneous component occurred in 2 patients probably due to a scarce number of perforators, or for excessive tension or compression of the perforating vessels and muscular components during intraoral reconstruction. Complete success transfer of iliac crest free flaps in our series was $85.7 \%$. In our series, dental implants were not performed because of the lack of financial resources for this specific target.
Although DSS an OS are low due to loco-regional recurrence or distant metastases in total or subtotal glossectomy and despite we did not performed a quality of life assessment, the patients reconstructed with a vertical rectus abdominis muscle flap referred an improvement in the quality of life following reconstruction. Functional rehabilitation remains difficult but the use of the myocutaneous free flap has been demonstrated to deliver good outcomes [18]. In our series, the vertical rectus abdominis muscle flap was fixed anteriorly to the mandible and posteriorly to the base of tongue. The downfall of the larynx was avoided with the suspension of the hyoid bone to the mandible with non-absorbable suture. No vertical rectus abdominis muscle flap failure or visceral herniation was observed in the present series.

After adequate patient counselling, tracheostomy was considered temporarily necessary during 135 (98.5\%) of the 137 procedures performed in patients who did not undergo total laryngectomy $(n=7)$, in order to prevent aspiration of saliva and possible passage of massive amounts of blood in the case of post-operative haemorrhage. In our opinion, the risks correlated with massive haemorrhage of the upper aero digestive tract, which may be even fatal, justify the temporary use of a tracheotomy. 
The nasogastric feeding tube was routinely preferred for the supportive feeding since it was temporary and without potential mortality and morbidity as reported for percutaneous endoscopic gastrostomy [19].

Reconstructive failure almost doubles the patient's length of stay, and is strongly associated with in-hospital mortality, since it can result in exposure of the great vessels or skull base, or the development of a pharyngo-cutaneous fistula [20]. In our series, we observed 40 (27.8\%) postoperative complications, including $3(2.1 \%)$ flap failures. B.H. Haughey et al. reported a $57 \%$ rate of medical complication and a $29 \%$ of flap complications, including a $4 \%$ rate of complete flap failure [20].

Our patients who experienced free flap failure had a statistically significant longer hospitalization time $(p<0.005)$ compared with the mean hospitalisation time of the whole cohort of patients (54.8 days vs 23.9 days respectively).

The role of anticoagulants is controversial, and includes aspirin, low-molecular-weight dextran, and subcutaneous heparin $[22,23]$. Despite the increased risks of hematoma related to all the antithrombotic medicaments (most of all the aspirin) and the absence of general consensus on their efficacy in failure prevention, the morbidity represented by the loss of a free flap leaded us to systematically treat our patients with a daily dose of low-weight subcutaneous heparin and this protocol, that is also used for deep vein thrombosis prevention, appeared to be reliable [21, 22]. There are still no evidence-based guidelines for the prevention of microvascular thrombosis in the head and neck [21, 22]. Therefore, microsurgeons must evaluate carefully the clinical features of all flaps, since early detection of thrombosis is of primary importance and the chance of surgical salvage is lower after the first 48 hours of ischemia [23], as a consequence, flap monitoring should be compulsory during the first 48 postoperative hours, and clinical monitoring four times daily should be sufficient thereafter. Among microvascular surgeons, postoperative monitoring regimens vary greatly, including close observation of the flap colour (used by $79.4 \%$ of surgeons), Doppler signal (used by $79.4 \%$ of surgeons), hourly "flap monitoring pin prick", and bleeding rate (used by $67.6 \%$ of surgeons), capillary refill (used by $61.8 \%$ of surgeons), skin surface temperature (used by $11.8 \%$ of surgeons), and implanted Doppler (used by $8.8 \%$ of surgeons) [24], but in our opinion, clinical observation remains the simplest method of identifying vascular compromise.

In our series, we reported a percentage of surgical revision of the anastomosis of $5.5 \%$ (8 out of 144) comparable to the data reported in literature $(4.5-17.0 \%)[1,25]$.

Three patients of our microsurgical series experienced a flap failure (jejunum flap, iliac crest and forearm flap). In all cases the flap was replaced with a pectoralis major pedicled flap.

Worldwide, a large number of patients undergoing microvascular free flap reconstruction are initially admitted to ICU on the premise of improved reconstructive outcomes.
In our series, admission to ICU was not associated with lower incidence of complications compared to direct admission to the head and neck ward: $29.4 \%$ vs $27.3 \%$ $(p=0.807709)$.

Although routine ICU care is presumed to improve postoperative care and contribute to a lower incidence of flap failure, in our analysis, flap failure was higher in patients of the ICU group (5.9\% vs $0.9 \%$ ), probably due to many factors, particularly the potential bias of the surgical learning curve. However, patients managed in the ward remained compliant for the examination of oral and oropharyngeal flaps and physiologic blood pressure parameters were observed routinely without a negative impact on the vascularisation of the transferred tissue.

Our results are in line with the most recent findings of the literature, confirming that protocol-driven non-ICUbased care can support successful reconstructive outcomes with comparable safety to ICU early admission routine [26]. Furthermore, avoiding ICU admission can reduce length of hospitalization and overall costs of care in both academic and community-based institutions.

In literature age alone is not a reliable prognostic factor for predicting medical complications, but it should be related with general health status, since an American Society of Anesthesiologists score of 3 is a statistically significant prognostic factor for medical complications, and diabetes mellitus, advanced atherosclerosis or other cardiovascular diseases impair the quality of the vessel wall and wound healing in general [27].

By using the AACCI, the authors characterized the impact of age and comorbidity on postoperative outcomes, and we found a not statistically significant higher surgical complication rate in the elderly group $(36.4 \%$ of the elderly patients vs $25.2 \%$ in younger patients; $p=0.171817$ ), while we observed a significant higher morbidity rate in young patients with AACCI $>5(52.9 \%$ vs $20.2 \%$ in young patients with AACCI $\leq 5 ; p=0.022812$ ). These data should be evaluated with caution since in our series elderly patients with poorer general conditions were reconstructed with less complex approaches to reduce postoperative risks, while young patients, even with important comorbidities, were generally treated with free flaps as to obtain better functional and aesthetic benefits.

Elderly patients admitted in ICU $(n=5)$ experienced higher complication rate compared to the 28 elderly patients admitted in the ward (60\% vs $32.1 \% ; p=0.232959)$, and it was mainly due to the higher AACCI index of these patients (those admitted in the ICU presented AACCI $>5$ ). Patients with AACCI $\leq 5$ admitted in the ICU $(n=12)$ experienced similar complication rate of the 105 patients with AACCI $\leq 5$ admitted in the ward $(16.7 \%$ vs $21.9 \%, p=$ $0.674953)$. ICU stay was associated with longer although not statistically significant stay in the hospital, probably as a consequence of a longer rehabilitation time due to the major in-bed stay of ICU patients. 
The aim of curative surgical oncology is to remove the primary tumour with a wide margin of normal tissue, but what constitutes a sufficiently wide margin particularly in oral cancer is fundamentally unclear.

The use of microvascular free flaps improves the oncologic radicality, allowing the surgeon to repair even larger defect. Our patients with head and neck squamous cell carcinoma $(n=135)$ experienced 5-year DSS, OS and RFS rate of $72.4 ; 60.6$ and $67.5 \%$, respectively, patients with oral cancer of stage I-II experienced 5-yaer DSS, OS, and RFS rate of $91.5 ; 74$ and $85.3 \%$ respectively, patients with oropharyngeal cancer of stage I-II experienced 5-year DSS, OS, and RFS rate of 100; 75 and $100 \%$ respectively, and those with advanced pharyngo-laryngeal tumours experienced 5-year DSS, OS, and RFS rate of 62.5; 60 and $62.5 \%$ respectively, patients with advanced squamous cell carcinoma of the facial skin experienced 5-year DSS, OS, and RFS rate of $100 ; 88.9$ and $72.9 \%$ respectively; these results show as free flaps reconstruction associated with a radical compartmental surgery allowed a positive curative in our series of patients (G. Almadori et al. reported 5-year DSS rate of $67.8 \%$ in a series of 130 patients with oral cancer [28], F. Bussu et al. reported a 5-year DSS rate of $82 \%$ in their series of patients with advanced malignancy of the parotid area [29], and F.T. Hall et al. reported 5-year DSS rate of $67 \%$ for patients with cancer of the larynx and $37 \%$ for those with cancer of the hypopharynx [30]).

\section{Conclusion}

A precise preoperative evaluation tailored to each patient on the basis of the functional age is mandatory to select the best candidates for head and neck microsurgical reconstruction. All our flap failures occurred during the first 31 cases in what could be considered our learning curve, and during the last 113 procedures we did not experience further failures. The improvement of our results leaded to an overall flap success rate of $97.9 \%$. Early postoperative admission to ICU seems not to improve outcomes and/or reduce complications. ICU admission should be restricted to selected patients only. More research is needed to confirm safety of post-operative treatment of head and neck free flap reconstruction without ICU admission.

\section{Л И}

1. Kucur C., Durmus K., Uysal I.O. et al. Management of complications and compromised free flaps following major head and neck surgery. Eur Arch Otorhinolaryngol 2016;273(1):209-13. DOI: $10.1007 / \mathrm{s} 00405-014-3489-1$. PMID: 25575841

2. Calabrese L., Tagliabue M., Maffini F. et al. From wide excision to a compartmental approach in tongue tumors: what is going on? Curr Opin Otolaryngol Head Neck Surg 2013;21(2):112-7. DOI: 10.1097/MOO.0b013e32835e28d2. PMID: 23422314.

3. Arshad H., Ozer H.G., Thatcher A. et al. Intensive care unit versus non-intensive care unit postoperative management of head and neck free flaps: comparative effectiveness and cost comparisons. Head Neck 2014;36(4):536-9. DOI: $10.1002 /$ hed.23325. PMID: 23780531.

4. Chang C.M., Yin W.Y., Wei C.K. et al. Adjusted age-adjusted Charlson comorbidity index score as a risk measure of perioperative mortality before cancer surgery. PLOS One 2016;11(2):e0148076. DOI: 10.1371/journal.pone.0148076. PMID: 26848761.

5. Amin M.B., Greene F.L., Edge S.B. et al. The Eighth Edition AJCC Cancer staging manual: continuing to build a bridge from a population-based to a more "personalized" approach to cancer staging. CA Cancer J Clin 2017;67(2):93-9.
DOI: $10.3322 /$ caac. 21388 . PMID: 28094848.

6. Genden E.M., Rinaldo A., Suárez C. et al. Complications of free flap transfers for head and neck reconstruction following cancer resection. Oral Oncol 2004;40(10): 979-84. DOI: 10.1016/j.oraloncology. 2004.01.012. PMID: 15509488.

7. Monteiro E., Sklar M.C., Eskander A. et al. Assessment of the Clavien-Dindo classification system for complications in head and neck surgery. Laryngoscope 2014;124(12):2726-31. DOI: 10.1002/lary. 24817. PMID: 25263590.

8. Dimovska E.O., Clibbon J.J., Moncrieff M.D. et al. Microsurgical reconstructions for head and neck cancers in elderly aged $>80$ years: an analysis of surgical outcomes and quality of life. Ann Surg Oncol 2016;23(5):1684-92. DOI: $10.1245 / \mathrm{s} 10434-015-5049-3$. PMID: 26714952.

9. Gooi Z., Richmon J., Agrawal N. et al. Education Committee of the American Head and Neck Society (AHNS). AHNS Series: do you know your guidelines? Principles of radiation therapy for head and neck cancer: a review of the National Comprehensive Cancer Network guidelines. Head Neck 2017;39(2):201-5. DOI: $10.1002 /$ hed. 24635.

PMID: 27898198.

10. Roman B.R., Goldenberg D., Givi B. Education Committee of American Head and Neck Society (AHNS). AHNS Series: do you know your guidelines? Guideline recommended follow-up and surveillance of head and neck cancer survivors. Head Neck 2016;38(2):168-74. DOI: 10.1002/ hed. 24100. PMID: 25916656.

11. Razzano S., Esposito L., Schonauer F. The venae comitantes clipping test for the evaluation of the venous drainage of the radial forearm free flap. Microsurgery 2016;36(8):647-50. DOI: $10.1002 /$ micr. 22514 . PMID: 26503001.

12. Hanasono M.M. Discussion: comparison of single and double venous anastomoses in head and neck oncologic reconstruction using free flaps: a meta-analysis. Plast Reconstr Surg 2016;137(5):1595-6. DOI: $10.1097 /$ PRS.0000000000002124. PMID: 27119932.

13. Chalian A.A., Anderson T.D., Weinstein G.S., Weber R.S. Internal jugular vein versus external jugular vein anastamosis: implications for successful free tissue transfer. Head Neck 2001;23(6):475-8. PMID: 11360309.

14. Jaquet Y., Enepekides D.J., Torgerson C., Higgins K.M. Radial forearm free flap donor site morbidity: ulnar-based transposition flap vs split-thickness skin graft. Arch Otolaryngol Head Neck Surg 2012;138(1):38-43. DOI: 10.1001/ archoto.2011.216. PMID: 22249627.

15. Costa H., Zenha H., Sequeira H. et al. Microsurgical reconstruction of the maxilla: algorithm and concepts. 
J Plast Reconstr Aesthet Surg 2015;68(5):e89-104. DOI: 10.1016/j.bjps. 2014.12.002. PMID: 25778873.

16. Puxeddu R., Ledda G.P., Siotto P. et al. Free-flap iliac crest in mandibular reconstruction following segmental mandibulectomy for squamous cell carcinoma of the oral cavity. Eur Arch Otorhinolaryngol 2004;261(4):202-7. DOI: $10.1007 / \mathrm{s} 00405-003-0656-1$. PMID: 15103472.

17. Lonie S., Herle P., Paddle A. et al. Mandibular reconstruction: meta-analysis of iliac-versus fibula-free flaps. ANZ J Surg 2016;86(5):337-42. DOI: 10.1111/ ans.13274. PMID: 26331293.

18. Cappiello J., Piazza C., Taglietti V. Nicolai P. Deep inferior epigastric artery perforated rectus abdominis free flap for head and neck reconstruction. Eur Arch Otorhinolaryngol 2012;269(4):1219-24. DOI: $10.1007 / \mathrm{s} 00405-011-1749-\mathrm{x}$. PMID: 21866360.

19. Rahnemai-Azar A.A., Rahnemaiazar A.A., Naghshizadian R. et al. Percutaneous endoscopic gastrostomy: indications, technique, complications and management. World J Gastroenterol 2014;20(24):7739-51. DOI: 10.3748/wjg. v20.i24.7739. PMID: 24976711.

20. Haughey B.H., Wilson E., Kluwe L. et al. Free flap reconstruction of the head and neck: analysis of 241 cases. Otolaryngol
Head Neck Surg 2001;125(1):10-7. DOI: $10.1067 / \mathrm{mhn} .2001 .116788$. PMID: 11458207.

21. Brands M.T., Van den Bosch S.C., Dieleman F.J. et al. Prevention of thrombosis after microvascular tissue transfer in the head and neck. A review of the literature and the state of affairs in Dutch Head and Neck Cancer Centers. Int J Oral Maxillofac Surg 2010;39(2):101-6. DOI: 10.1016/j.ijom. 2009.11.020. PMID: 20042315.

22. Lee K.T., Mun G.H. The efficacy of postoperative antithrombotics in free flap surgery: a systematic review and metaanalysis. Plast Reconstr Surg 2015;135(4): 1124-39. DOI: 10.1097/PRS. 0000000000001100 . PMID: 25811576.

23. Hyodo I., Nakayama B., Kato H. et al. Analysis of salvage operation in head and neck microsurgical reconstruction. Laryngoscope 2007;117(2):357-60. DOI: $10.1097 / \mathrm{mlg} .0 \mathrm{~b} 013 \mathrm{e} 3180312380$. PMID: 17277633.

24. Spiegel J.H., Polat J.K. Microvascular flap reconstruction by otolaryngologists: prevalence, postoperative care, and monitoring techniques. Laryngoscope 2007;117(3):485-90. DOI: 10.1097/ MLG.0b013e31802d6e66. PMID: 17334309.

25. Yii N.W., Evans G.R., Miller M.J. et al. Thrombolytic therapy: what is its role in free flap salvage? Ann Plast Surg 2001;46(6):601-4. PMID: 11405358.

26. Panwar A., Smith R., Lydiatt D. et al. Vascularized tissue transfer in head and neck surgery: is intensive care unit-based management necessary?

Laryngoscope 2016;126(1):73-9.

DOI: 10.1002/lary. 25608 .

PMID: 26343412.

27. Rosenberg A.J., Van Cann E.M., van der Bilt A. et al. A prospective study on prognostic factors for free-flap reconstructions of head and neck defects. Int J Oral Maxillofac Surg 2009;38(6): 666-70. DOI: 10.1016/j.ijom. 2009.01.012. PMID: 19264448.

28. Almadori G., Rigante M., Bussu F. et al. Impact of microvascular free flap reconstruction in oral cavity cancer: our experience in 130 cases. Acta Otorhinolaryngol Ital 2015;35(6):386-93. DOI: $10.14639 / 0392-100 X-919$. PMID: 26900243.

29. Bussu F., Parrilla C., Rizzo D. et al. Clinical approach and treatment of benign and malignant parotid masses, personal experience. Acta Otorhinolaryngol Ital 2011;31(3):135-43. PMID: 22058591.

30. Hall F.T., O'Brien C.J., Clifford A. R. et al. Clinical outcome following total laryngectomy for cancer. ANZ J Surg 2003;73(5):300-5. PMID: 12752286.

\section{Authors' contributions}

The authors declare that this manuscript was conceived and written by the cited authors.

Вклад авторов

Авторы заявляют, что данная статья была задумана и написана перечисленными авторами,

ORCID авторов / ORCID of authors

R. Puxeddu / Р. Пукседу: https://orcid.org/0000-0003-2829-0583

Conflict of interest. The authors do not have to disclose financial information, and they confirm no conflict of interest concerning this manuscript. Конфликт интересов. Авторы заявляют, что нет необходимости в разглашении финансовой информации; конфликт интересов отсутствует.

Financing. All authors declare that does not exist any financial support or relationship that may pose a conflict of interest.

Финансирование. Все авторы заявляют, что при выполнении исследования не получали какой-либо финансовой поддержки, которая могла бы привести к возникновению конфликта интересов.

Статья поступила: 21.08.2018. Принята к публикации: 28.09.2018.

Article received: 21.08.2018. Accepted for publication: 28.09.2018. 